\title{
TCHECOSLOVÁQUIA EM 1968: A CONSTRUÇÃO DO SOCIALISMO INTERROMPIDA
}

\author{
Wanderson Fábio Melo ${ }^{1}$
}

RESUMO: O tema do presente texto é a Primavera de Praga, os acontecimentos na Tchecoslováquia em 1968. As problemáticas se relacionam em buscar as posições dos diferentes sujeitos, o processo que levou à invasão pelos países do Pacto de Varsóvia e o surgimento dos conselhos operários. As fontes são os textos produzidos pelos sujeitos históricos envolvidos.

Palavras-chave: Tchecoslováquia 1968. Primavera de Praga. Socialismo.

\section{CZECHOSLOVAKIA IN 1968: THE CONSTRUCTION OF INTERRUPTED SOCIALISM}

ABSTRACT: The theme of this text is the Spring of Prague, the events in Czechoslovakia in 1968. The problems are related in searching the positions of the different subjects, the process that led to the invasion by the countries of the Warsaw Pact and the emergence of workers' councils. The sources are the texts produced by the historical subjects involved.

Keywords: Czechoslovakia 1968. Prague Spring. Socialism.

\section{CHECOSLOVAQUIA EN 1968: LA CONSTRUCCIÓN DEL SOCIALISMO INTERRUMPIDA}

RESUMEN: El tema del presente texto es la Primavera de Praga, los acontecimientos en Checoslovaquia en 1968. Las problemáticas se relacionan en buscar las posiciones de los diferentes sujetos, el proceso que llevara a la invasión por los países del Pacto de Varsovia y el

1 Doutor em História Social, professor na UFF, Campus de Rio das Ostras. Endereço eletrônico: wfabiomelo@yahoo.com.br. 
surgimiento de los consejos obreros. Las fuentes son los textos producidos por los sujetos históricos presentes nos acontecimientos.

Palabras clave: Checoslovaquia 1968. Primavera de Praga. Socialismo.

\section{Introdução: os sujeitos em movimentos}

Nesse cinquentenário de 1968 torna-se importante desfazer algumas confusões. Ao recuperar os acontecimentos ocorridos na Tchecoslováquia, alguns textos publicados na imprensa de grande circulação têm expressados certos pontos de vistas que não favorece a elucidação do evento histórico protagonizado por estudantes, intelectuais, artistas, acadêmicos e trabalhadores que ficou conhecido como a Primavera de Praga. A maior parte dos artigos em jornais e revistas sobre o 68 tchecoslovaco, publicados nos últimos anos, basicamente se divide em duas tendências; a primeira, frisa a invasão russa, com o intuito de ressaltar a disposição daquele país em desenvolver ações imperialistas e agressivas, chegando mesmo a ocupar outra nação visando a impor a sua política. Dito de outro modo, parte da imprensa sublinha o aspecto do agressivismo russo na política externa de forma a-histórica. Por sua vez, a outra posição exalta os dirigentes reformadores da Tchecoslováquia, insinuando que a eles coube a formulação do projeto mobilizador que ascendeu junto ao povo; nessa interpretação, as mobilizações populares foram caudatárias às lideranças políticas, que lutavam pelo "socialismo de face humana". Vale destacar que essas visões distintas acerca dos eventos no ano de 1968 na Tchecoslováquia refletem posições no presente. A primeira interpretação remete aos adversários e críticos da política externa da Rússia no momento atual; enquanto a segunda, vincula-se aos desígnios dos que batalham pelo movimento subordinado às lideranças políticas, sem priorização de ações autônomas dos sujeitos na perspectivas de suas realizações.

Torna-se relevante considerar que nas reflexões sobre a história sempre se retorna aos acontecimentos passados com as preocupações estabelecidas no presente. Segundo Walter Benjamin: "A história é objeto de uma construção cujo lugar não é o tempo vazio, mas um tempo saturado de "agoras"' (1994, p. 229). Assim sendo, a leitura histórica não pode ser a mera transposição de situações de modo anacrônico, uma vez que se deve considerar o contexto, as ações vividas e os anseios dos sujeitos envolvidos. Nesse passo, para uma reflexão consistente torna-se necessário buscar o sentido da Primavera de Praga por meio do processo de sua historicidade, os sujeitos históricos e as suas propostas, as mobilizações populares e os impactos no campo social e político. 
Foge ao escopo deste trabalho uma avaliação sistematizada do que foi a formação social desenvolvida no Leste Europeu e na União Soviética. Reconhece-se que essa é uma discussão necessária para a compreensão da dinâmica social e política ampla sobre o socialismo e a sua crise. No entanto, neste texto, busca-se os sujeitos históricos em movimentos na Tchecoslováquia em 1968 por suas ações e propostas explicitadas nos embates sócio-políticos.

Considera-se que se vivenciou em 1968 na Tchecoslováquia um processo revolucionário, compreendendo por revolução a situação em que a massa de homens e mulheres normalmente apática começa a participar de maneira ativa na vida social, quando adquire consciência de sua força e se move para tomar o destino em suas mãos.

Deve-se pontuar a existência de especificidades no caso da sociedade de transição posta na Tchecoslováquia. No país havia sido superada a propriedade privada por meio de um processo revolucionário em 1948, mas o comando social ficou sob o domínio de uma casta burocrática que expropriava politicamente o proletariado, impedindo a realização da democracia operária. As ações de diferentes sujeitos empenhados na Primavera de Praga revelou os esforços para se trilhar um novo caminho com vistas à sociedade de transição em busca do socialismo. De acordo com o historiador Pierre Broué, ao analisar os acontecimentos tchecoslovacos em 1968, pode-se afirmar que esboçaram-se, "sem formular, a perspectiva da necessidade de uma revolução política que completaria a revolução social de 1948" (1979, p. 39). Deve-se realçar que os movimentos na Tchecoslováquia em 1968 não desfraldaram a consigna de "revolução política", mas o sentido de várias das reivindicações caminhou nessa direção. Em outras palavras, os sujeitos mobilizados concordavam com a transformação social de superação da propriedade privada, mas lutavam para tomar as deliberações políticas das mãos da burocracia partidária e estatal, de modo a construir o socialismo com base na participação popular. Contudo, essa construção foi interrompida por meio da invasão dos exércitos dos países do Pacto de Varsóvia, liderados pela URSS, e pela colaboração política da burocracia no poder com o intuito de apaziguamento das forças sociais que afloravam.

\section{O socialismo da Tchecoslováquia}

Do século XIX até a I Guerra Mundial, os tchecos e os eslovacos compunham o Império Austro-Húngaro. Depois da Guerra, com o desmembramento do Império, formou-se a primeira República Tchecoslováquia, a partir da soma das regiões habitadas pelos tchecos e os eslovacos, povos da Morávia, Silésia e Eslováquia, na Europa Central. Essa República perdurou de 1918 a 1938, quando sofreu a invasão da Alemanha Nazista, abrindo-se a segunda fase da história 
política do país que durou de 1938 a 1945. Vale destacar que a Tchecoslováquia antes da dominação nazista possuía um movimento operário com certa expressão social, com sindicatos, com Partidos Socialdemocrata e Comunista. Segundo Vladimir Kusin (1971, p. 4), em 1927 o PCT (Partido Comunista da Tchecoslováquia) contava com cerca de 138.000 filiados; entretanto, o número caiu para 40.000 em 1931, após a crise no movimento dos trabalhadores, que se relaciona a ascensão de Josef Stálin na URSS e na Internacional Comunista.

Em cinco de maio de 1945, o povo no país da Europa Central insurgiu contra o nazismo, quatro dias depois os russos libertaram Praga, estabeleceu-se a terceira fase da República Tchecoslováquia, momento no qual a sua estrutura social e política evidenciou relação à influência soviética. Nessa etapa, constituiu-se um socialismo por meio da pressão do Exército Vermelho, seguindo o modelo russo daquele momento, isto é, não se verificou na Tchecoslováquia do pós-II Guerra o processo revolucionário dos conselhos e do controle dos trabalhadores sobre a produção, como na experiência da Revolução Russa de 1917 dirigida pelos bolcheviques. Desde o início do socialismo na Tchecoslováquia, o sistema social e político foram verticalizados, tratou-se de um socialismo burocrático, tendo como modelo a União Soviética sob a mão forte de Josef Stálin. Em 1948, segundo Kusin:

\footnotetext{
O monopólio do poder do Partido Comunista foi levado ao limite máximo enquanto correias de transmissão, alavancas e engrenagens de uma máquina. $\mathrm{Na}$ Tchecoslováquia não houve ação política independente do Partido Comunista. Dentro do Partido ocorreu a formação de hierarquias, que logicamente levou à concentração de poder em grupos, à cabeceira dos vários níveis do aparato e, finalmente, em um pequeno grupo de homens no topo, que se tornaram superiores nos organismos partidários (1971, p.9).
}

Torna-se lídimo considerar que na Tchecoslováquia nos anos de 1949 a 1954 ocorreram expurgos no interior do Partido Comunista, que impôs a hegemonia stalinista, o que levou ao extermínio de adversários, fixou-se uma visão monolítica de construção do socialismo, na medida em que foi realçado o percurso apontado pela União Soviética burocratizada como o único caminho socialista a ser seguido. Em outras palavras, os projetos socialistas distintos aos do stalinismo foram descartados e perseguidos no processo de instauração e consolidação socialista no país da Europa Central.

A Tchecoslováquia aderiu ao Pacto de Varsóvia no contexto da Guerra Fria, evidenciando a sua relação com os países do Leste Europeu e do bloco liderado pela União Soviética, a principal potência militar da coalizão. Nesse passo, o país não trilhou o caminho de independência em relação à URSS, como a Iugoslávia desde o final da II Guerra, ou a Romênia dos anos 60 do século XX. 
A direção da estrutura social do partido único e do Estado tchecoslovaco estava nas mãos de Antonin Novotny e de seu grupo político. Novotny ocupava a secretaria geral do PCT desde 1953, e acumulou a função de Primeiro Ministro a partir de 1957. Sua carreira se fez após expurgos de dirigentes não confiáveis aos soviéticos, bem como no contexto de consolidação do partido único frente ao Estado. Ele era o representante das forças burocráticas do PCT, artífice da ditadura na Tchecoslováquia e um submisso à URSS.

Torna-se pertinente registrar que na Tchecoslováquia o processo de desestalinização se processou com menor impacto comparativamente em relação ao que se deu na União Soviética. O conhecido informe de Nikita Kruschev ao XX Congresso do PCUS, em 1956, resultou na elaboração crítica a Stálin, reconhecendo alguns de seus crimes e o "abuso ao culto à personalidade”. Contudo, vale destacar que a desestalinização kruschevista não questionou a base do sistema burocrático da URSS, isto é, não evidenciou a questão da expropriação política que as burocracias do Estado e do Partido impuseram aos trabalhadores; tampouco reconheceu o extermínio de uma geração de revolucionários levada à cabo por Stálin durante os Processos de Moscou, entre 1936 e 1938. Na Tchecoslováquia, ocorreram crimes similares aos praticados pela camarilha dirigente da URSS, com processos falsificados, crimes políticos e expurgos nos anos de 1949 a 1953. A esse respeito, pode-se considerar o Processo Slánsky. O dirigente Rudolf Slánsky foi secretário geral do PCT nos anos de 1944 a 1951 e vice primeiro-ministro. Contra ele montou-se a farsa jurídica que levou à sua condenação juntamente com várias autoridades do país ${ }^{2} ;$ implementando-se no país da Europa Central os expurgos semelhantes aos do regime soviético na fase de Stálin. A maioria dos réus foi condenada à morte, sendo a alguns dirigentes imputada a pena de prisão perpétua. Slánsky foi enforcado em dezembro de 1952. Com a "desestalinização" tchecoslovaca, ele foi reabilitado ao nível penal em 1963. A reabilitação política ocorreu em 1968.

Comparada à intervenção de Kruschev, a desestalinização tchecoslovaca foi ainda mais limitada, visto que a direção novotyniana optou por ocultar aos membros do partido e aos cidadãos as dimensões dos crimes políticos dos seguimentos dirigentes sobre os adversários no interior do Partido. Esta questão era sensível, porque Novotny e alguns de seus próximos colaboradores haviam chegado ao poder graças à sua função em tais processos.

As contestações realizadas por operários ao "socialismo" apareceram na Tchecoslováquia nos anos 50 do século XX. Segundo Fernando Claudin:

\footnotetext{
${ }^{2}$ A esse assunto, conferir Löbl; Pokorny (1968) e Tigrid (1968).
} 
No dia $1^{\circ}$ de junho de 1953 os trabalhadores de vários centros industriais da Tchecoslováquia iniciaram paralisações e manifestações especialmente importantes na grande empresa CKD de Praga, na siderurgia e nas minas de Ostrava e, sobretudo, na grande fábrica Lênin (antiga Skoda) de Pilsen. O detonador havia sido uma reforma monetária que prejudicava duramente o povo, mas imediatamente aparecem as intenções políticas que animam os protagonistas. A manifestação operária de Pilsen assalta a sede do poder local e exige eleições livres. Arrancam os retratos de Gottwald [líder do país] e Stálin, rasgam as bandeiras soviéticas. As milícias (forças governamentais de ordem pública) confraternizam com os manifestantes. Para restabelecer a ordem o governo tem que enviar de Praga unidades do exército. Algo semelhante acontece em outras cidades (1983, p. 152).

Entretanto, a mobilização dos trabalhadores tchecoslovacos não ocorreu com a mesma intensidade como na Polônia de 1956, que vivenciou o levante operário de Poznan, ou como na Revolução Húngara no mesmo ano, quando a população armada enfrentou o poder de Estado. Nas duas situações foram necessárias as intervenções das tropas soviéticas para o restabelecimento da ordem. Assim sendo, em relação Tchecoslováquia, por um lado, não se pode afirmar que o país seguiu em águas calmas no processo político, por outro, deve-se reconhecer que o aparato do Estado praticou o controle social, conservando o domínio da burocracia.

O socialismo burocrático instaurado na Tchecoslováquia não contemplava a participação popular nas decisões sobre a vida social. As instâncias decisórias eram formadas pelo PCT e o Estado, de modo que inexistia o conselho operário, ou órgão de construção desde a base. Tampouco foi permitido a organização política distinta ao partido no poder. Sendo assim, não havia o pluralismo, visto que a estrutura de partido único na condução estatal seguia o exemplo da URSS, o que impedia o debate político amplo e a previsão de decisões respaldadas nos anseios dos trabalhadores. O proletariado seguia expropriado politicamente pela burocracia no poder.

No encaminhamento dos temas da cultura, na Tchecoslováquia socialista as reflexões artísticas e culturais estavam subordinadas à linha política do partido único, o que impunha limites às reflexões intelectuais. A produção de conhecimento servia ao controle social pela burocracia encastelada no Estado. As informações que circulavam na imprensa sofriam a cesura por parte das autoridades do Partido e do Estado. Entretanto, a intelectualidade tchecoslovaca passou a questionar a situação de arbítrio com vistas a construir um novo rumo à política cultural do socialismo, isto é, a intelligentsia lutava para libertar a cultura da ditadura burocrática. Os intelectuais passaram a problematizar a questão cultural no país que, na visão da maioria deles, estava reduzida a um mero instrumento de propaganda do regime.

Nas questões econômicas, o país da Europa Central também seguia o modelo soviético de priorização da indústria pesada em detrimento à produção de bens de consumo para a 
população. A construção de moradias na Tchecoslováquia, nos anos 60 do século XX, encontrava-se negligenciada. Havia o atraso na construção de escolas e de equipamentos médicos; a eletrônica não teve desenvolvimento adequado no país. Ademais, a crise material se aprofundava devido ao fracasso do governo na política econômica, que desfavoreceu aos trabalhadores, por conta do mais baixo índice de aumento da produção industrial de toda a Europa Oriental. De acordo com Pierre Broué:

\begin{abstract}
O balanço econômico parecia catastrófico: equipamentos velhos não renovados, custos de produção cada vez mais crescentes, lentidão desesperante da construção, aumento do subequipamento do campo e baixa constante da produção agrícola eram os traços mais evidentes. A imitação servil dos métodos russos de planificação burocrática, a prioridade dada aos investimentos na indústria pesada, a reconversão do comércio exterior para o Leste, o lugar privilegiado ocupado pela União Soviética nessas trocas e as condições desiguais dos mesmos foram as causas gerais, tendo a ruptura das relações comerciais com a China dado proporções de catástrofes à perturbação industrial. Acima de tudo prevalecia o sentimento de uma incapacidade total do regime nesse plano: as empresas, sem iniciativa, encerradas no círculo das cifras da produção, não se preocupavam com a economia nem com a qualidade, e a máquina girava por si mesma sob administradores incompetentes e de qualquer maneira impotentes (1979, p. 37).
\end{abstract}

A crise econômica agravou a fissura no interior da burocracia tchecoslovaca. O setor dominante no Partido e no Estado, até então, propalava a permanência do planejamento centralizado burocraticamente, enquanto, por outro lado, os diretores de fábrica, os especialistas, os engenheiros, os técnicos qualificados, os professores e os médicos almejavam a reforma da gestão com vistas à eficácia e a recomposição produtiva, por meio de medidas descentralizadoras.

\title{
3. A Primavera de Praga
}

A contestação ao socialismo burocrático teve o seu início na juventude universitária. Em 1965, a união da Juventude Comunista exigia autonomia para poder expressar e levar as opiniões dos jovens sobre a vida social às instâncias partidária, estatal e universitária. Em novembro de 1966, as forças contrárias à direção do Partido conquistou a maioria no comitê estudantil da Universidade de Praga; concomitantemente a esse processo surgiram inúmeras peças teatrais, livros e filmes que denunciavam a época stalinista e revelavam as contradições do socialismo tchecoslovaco.

Em junho de 1967 ocorreu o IV Congresso dos Escritores, que ampliou a crítica ao regime, na medida em que exigiu: "liberdade total de palavra, de pensamento e criação", o fim da "censura política", e solidariedade ao escritor Alexander Soljenítsin, intelectual perseguido pelo Estado soviético. 
No inverno, os estudantes se manifestaram devido ao corte de energia elétrica, com duração de três dias, sofrido nos alojamentos residenciais; eles seguiram em passeatas pelas ruas com velas nas mãos e cartazes escritos "Dai-nos luz!” As forças do Estado reprimiram o movimento. Cutka, um alto funcionário do Comitê Central do PCT, observou a um jornalista estrangeiro: "Pela primeira vez na história de nossa República, crianças nascidas e criadas sob o regime, não tendo recebido nenhuma influência além da educação socialista, foram espancadas pela polícia e exibiam slogans hostis ao governo e ao partido" (apud, Broué, 1979, p. 47).

Após a repressão, parte da burocracia do PCT passa a negociar com os estudantes, prometendo a punição dos responsáveis pelos atos repressivos; os dirigentes estudantis enfatizaram que se os jornais não publicassem o ocorrido, eles seguiriam às fábricas para explicar os acontecimentos aos trabalhadores. Nesse passo, ganha força a independência dos meios de comunicação sobre as instâncias do Estado e do Partido, os profissionais da imprensa batem por maior autonomia em seu trabalho, de modo que se amplia a onda contestatória, construindo-se, na prática, a abolição da censura e a formação da imprensa livre.

Sendo assim, pode-se perceber que os estudantes transferem as batalhas do interior das instâncias partidárias para às ruas, organizando manifestações. Nesse passo, a imensa maioria da intelectualidade e dos estudantes passam à oposição política ao grupo novotinysta que ocupava o poder.

A questão nacional foi outro elemento que esteve na raiz da Primavera de Praga. A Eslováquia havia sido "riscada" no Império Austro-Húngaro; com a primeira República Tchecoslováquia, os eslovacos se sentiam colonizados pelos tchecos, visto que a região permanecia pobre, atrasada economicamente e com altos índices de analfabetos. Tampouco o socialismo tchecoslovaco resolveu o problema nacional, uma vez que a maioria dos quadros com funções dirigentes eram tchecos, ao passo que o trabalho com pouca qualificação era ocupado por eslovacos. Na Bratislava, a principal cidade eslovaca, era comum a crítica ao domínio do Castelo, nome dado pejorativamente pelos eslovacos a Praga, a capital tchecoslovaca, a principal cidade tcheca. Durante a atmosfera contestatória, o dirigente eslovaco Alexander Dubcek trouxe o tema da questão nacional para as instâncias do Partido. Ao reconhecer o problema e analisar a situação, Dubcek propôs a federalização do Estado; no entanto, obteve como resposta a agressão verbal, sendo chamado de "nacionalista burguês eslovaco". Sofreu insultos, xingamentos e ameaças diretas por parte de Antonin Novotny. Entretanto, as forças no poder passam a perder apoio e, por consequência, A. Dubcek torna-se 
a figura pública de proa, a principal liderança dos comunistas "renovadores" em oposição aos comunistas conservadores novotnystas.

Deve-se ressaltar que a contestação política, que veio dos estudantes e impactou a intelectualidade, foi somada pelos eslovacos com a questão nacional. Os profissionais da imprensa tiveram a sua importância no alargamento da luta contra a censura e pelo direito à informação livre. Toda essa efervescência contestatória impactou o PCT. Notou-se a ampla expressão social contestatória. Em suas memórias, A. Dubcek lembrou: "Nós percebemos a partir dos relatos dos comitês distritais do Partido que o estado de ânimo do público na Eslováquia e nas terras tchecas era cada vez mais impaciente e a favor das mudanças” (1993, p. 112). Nota-se que a ala renovadora conseguiu captanear a insatisfação social trazendo os assuntos às instâncias partidárias.

Com a eliminação de Novotny da Secretaria Geral do PCT, e a sua substituição por Dubcek, em 5 de janeiro de 1968, inicia-se o processo de transformação que foi impactado em 21 de agosto pela invasão das tropas do Pacto de Varsóvia, sob o comando da URSS. Durante 8 meses os trabalhadores e o povo tchecoslovaco cultivou passos decisivos no sentido de superação do regime stalinista na direção ao socialismo, foi a chamada Primavera de Praga. De acordo com os desígnios das lideranças da ala renovadora seria o "socialismo de face humana".

Mais uma vez, vale lembrar a particularidade tchecoslovaca na superação da propriedade privada. Distintamente de outros países que foram libertados da dominação nazista pelo Exército Vermelho, o PC na Tchecoslováquia havia constituído certa base social junto aos trabalhadores industriais, não sendo mera organização de vanguarda. No pós-II Guerra, o Kremlin impôs o modelo de pensamento único, para isso a direção comunista tchecoslovaca recorreu à repressão aos socialistas dissidentes, tornando o PCT uma organização monolítica e dócil aos soviéticos. Para tal situação, as autoridades estatais e do partido realizaram expurgos no interior de suas fileiras, retirando do cenário político e social os "socialistas heréticos", isto é, os ativistas que se recusavam a seguir a cartilha de Moscou, ou que expressaram divergências pontuais. Entretanto, na maré contestatória dos anos 60, os tchecoslovacos mobilizados passaram a exigir a reabilitação dos militantes silenciados e punidos no percurso do "socialismo" no país. Como notou Pierre Broué:

a questão das reabilitações estava longe de ser uma questão de simples justiça ou de simples moral. As reabilitações respondiam a uma exigência através da qual se exprimiam todas as aspirações de uma exigência através da qual se exprimiam todas as aspirações de uma sociedade oprimida durante anos sob o tacão de fero da burocracia $(1979$, p. 88$)$. 
Assim, no ascenso das lutas contestatória, as exigências de reabilitação, além de servirem para elucidar o passado, convinham aos embates que se processavam naquele instante, uma vez que ter a certeza da investigação e da responsabilização do opressor, mesmo que futura, intimidaria os agentes do Estado a cometerem crimes e arbitrariedades. Em síntese, a responsabilização dos repressores no passado era uma necessidade para defender os estudantes, a intelectualidade e os trabalhadores que lutavam naquele momento.

Quanto à questão do encaminhamento econômico, o programa da ala renovadora do PCT liderada por A. Dubcek contou com a adesão e a elaboração de Ota Sik, um quadro dirigente no Partido e ardente defensor das reformas econômicas. Ota Sik projetou medidas visando à "racionalização" da economia, por meio de um programa econômico semelhante ao desenvolvido na Iugoslávia, no qual as diretrizes do plano central estavam substituídas por planos elaborados pelas empresas ou associações de empresas. Em concomitância, os ideólogos da ala renovadora advogavam a ampliação da diferença salarial entre os diretores, os trabalhadores qualificados e não-qualificados. Sendo assim, os reformadores do PCT não questionavam os privilégios da burocracia dirigente, uma vez que o projeto liderado por Dubcek, ao defender a disparidade salarial, esperava gerar os recursos para a garantia do incentivo aos diretores de fábrica e a modernização do aparato produtivo. Alan Woods fez um apontamento importante acerca da base social da proposta do grupo renovador:

\footnotetext{
Um artigo publicado no The Sunday Times em 21 de julho de 1968 revelava de maneira caricatural o estrato social em que se baseava Dubcek para conseguir seu apoio. Em uma entrevista dada por um diretor de fábrica tchecoslovaco, este explicava quais eram suas razões para apoiar a nova direção reformista:

Agora na fábrica temos muito mais liberdade. Já não estão os mesmos velhos idiotas interferindo em nossa produção, podemos buscar os clientes nós mesmos, não temos problemas com as peças de substituição ou manutenção.

Mas os salários são um problema. O trabalhador médio ganha 2.100 coroas mensais, enquanto os engenheiros recebem apenas cerca de 6\% mais. Precisamos de uma diferença de, pelo menos, $30 \%$... (2008, p. 5)
}

O jornalista G. Water também considerou relatos de diretores propalando a diferenciação salarial como eixo central da proposta econômica dos renovadores:

\footnotetext{
A concorrência é uma questão de qualidade. É preciso voltar a habituarmo-nos a essa noção de que existem bons e maus operários. Se um funcionário com funções executivas ganha 3.000 coroas por mês, um motorista de caminhão outro tanto, um mineiro de 2.500 a 4.000 coroas nas minas de urânio e um trabalhador braçal 2.000 coroas, como querem incitar um jovem capaz de levantar uma picareta a estudar engenharia? (apud WALTER, 1968, p. 96).
}

Como se percebe, o projeto econômico da ala renovadora do PCT incorporava o universo imaginário dos diretores de fábricas, visto que para enfrentar à crise propunham o 
planejamento descentralizado e a diferenciação salarial favorável aos executivos e aos trabalhadores qualificados em detrimento dos trabalhadores do chão de fábrica.

Vale frisar que na Iugoslávia, onde o projeto de planificação descentralizada havia sido implantado, alavancou-se a produção industrial durante alguns anos; mas, na sequência, a economia teve de enfrentar a baixa no crescimento, uma vez que houve a "concorrência socialista" devido a racionalização e a descentralização, o que resultou no fechamento de empresas e, consequentemente, 300 mil trabalhadores iugoslavos ficaram desempregados em 1967.

Deve-se sublinhar que as reformas econômicas de A. Dubcek e Ota Sik além das distorções salariais, também afetariam aos interesses dos trabalhadores na medida em que a concorrência entre as empresas estatais resultaria inevitavelmente no fechamento das empresas menos rentáveis, levando ao desemprego em larga escala. Ademais, a proposição renovadora na economia induziria ao agravamento da situação da região com baixo grau de desenvolvimento das forças produtivas, como a Eslováquia, defasada em tecnologia, indústria e força de trabalho qualificada.

A proposta da ala renovadora não abandonava a economia burocraticamente planejada, tampouco incorporava a consigna do controle operário e os comitês de fábricas surgidas no ascenso de lutas operárias após março de 1968. Em síntese, a proposta dos renovadores expressava essencialmente a conciliação entre os interesses dos apparatchik (homens do aparelho burocrático do PCT e do Estado) e dos diregentes de fábrica. No plano político, devese ressaltar que Dubcek possuía extenso apoio entre os estudantes e intelectuais, seguimentos sociais simpáticos aos diretores fabris.

Na disputa social, o principal representante dos apparatchik, o então primeiro ministro A. Novotny alardeava que as reformas econômicas da ala renovadora do PCT comprometeriam as conquistas sociais dos trabalhadores e a segurança de seu emprego. Falava que o bloco renovador objetivava instituir um sistema no qual o diretor e os quadros com alta qualificação seriam os privilegiados. Segundo George Walter: "Novotny, em uma de suas últimas visitas à fábrica $\mathrm{CKD}$, tentou recuperar forças advertindo os operários de que suas conquistas estavam ameaçadas: 'Se ser conservador é querer preservar essas conquistas, então eu sou um conservador"” (1968, p. 95).

Verifica-se que a burocracia tradicional com base nos apparatchik adotava demagogicamente a retórica do obreirismo, isto é, o discurso que defendia a predominância do proletariado na condução da luta pela mudança na sociedade, negligenciando assim a 
possibilidade de alianças com setores como estudantes e intelectuais. A camada dirigente expropriadora política dos trabalhadores utilizava o recurso discursivo obreirista com o intuito de jogar os trabalhadores contra os estudantes e a intelectualidade, visando a enfraquecer politicamente a ala renovadora. Postulava o obreirismo sob o controle da burocracia. $\mathrm{Na}$ essência, o discurso novotnysta conservava o comando econômico e social no seguimento burocrático, com base na expropriação política do proletariado, uma vez que desconsiderava os trabalhadores no processo de tomada de decisões, tampouco se referia ao estabelecimento de órgãos como os conselhos operários nas fábricas.

Para a compreensão da crise tchecoslovaca de 1968 deve-se reconhecer que a contestação aflorou a partir dos assuntos relacionados às reivindicações da juventude, da intelectualidade contra a censura e da questão nacional eslovaca; na sequência, os questionamentos evoluíram para a contestação dos privilégios dos membros do círculo dirigentes. Como ressaltaram Rabey, Duarte e Bruno:

Em 22 de março, uma nota na imprensa sacudiu o país: 'Novotny e seu filho utilizavam uma licença governamental de importação para obter veículos Mercedes, Alfa Romeo, Jaguar e outras marcas ocidentais, para impressionar as mulheres. Quando se cansavam do veículo em particular, sempre podiam vendê-lo aos amigos com um benefício considerável (2008).

Novotny e vários de seu grupo foram obrigados a renunciar às funções dirigentes acusados de corrupção. Ascendeu ao poder Ludvik Svoboda, figura sensível à renovação, tornando-se o primeiro ministro. A dinâmica dos acontecimentos impulsionou a imprensa livre não estatal, que reivindicava ainda mais pluralismo, autonomia e independência. $\mathrm{O}$ avanço da crise revolucionária pôs em discussão a superação do partido único, o estabelecimento do controle operário da produção e trouxe a crítica aos elementos burocráticos da economia.

O movimento vai passando da universidade às fábricas. A partir de março, as reuniões fabris tornam-se abarrotadas, os oradores são cada vez mais numerosos e as reivindicações vão tomando formas, bem como as ações para garantir os seus propósitos. Como notou Pierre Broué:

Ameaças de greve e greves efetivas continuam: em 2 de abril são os chefes de equipe das ferrovias de Praga que, reunidos na estação central de Praga, reivindicam um aumento de escala; em seguida, é a vez dos bombeiros da capital que constituem um comitê de greve de doze membros e ameaçam entrar em greve no dia 12 de abril se não obtiveram satisfação das suas reivindicações, melhora das condições de trabalho, segurança e de equipamento. Em Optimit Idry, na região de Ostrava, os operários entram em greve porque a direção reteve 124000 coroas de prêmios indevidamente retidos, assim como a dispensa do diretor. Essas ações vitoriosas encorajam os hesitantes. Nos dias que seguem são anunciadas greves ou ameaças de greve imediatamente abandonadas porque a direção cede, na fábrica Sygma de bombas 
elétricas, na região de Olomouc, na estação de Havirov. Os trabalhadores do depósito de locomotivas de Praga formam um sindicato "autônomo", dirigido por comunistas estreitamente ligados ao "parlamento estudantil" de Praga (BROUÉ, 1979, p. 99).

Vale destacar que o seguimento operário foi sacudido a partir de março, uma vez que os trabalhadores desconfiava do programa da ala reformadora do PCT, que considerava a diferenciação salarial desfavorável ao pessoal do chão de fábrica, assim como vislumbrava a previsão de fechamento de postos de trabalho, medidas que não correspondiam aos interesses dos trabalhadores. Tal questão explica a demora do movimento operário em aparecer na Primavera de Praga. Entretanto, após o mês de março, o operariado tchecoslovaco passa a organizar os comitês de fábrica, a defender a autogestão, a combater o sindicalismo oficial por meio da organização autônoma e reconhecer a greve enquanto instrumento de lutas.

Nos assuntos econômicos, os trabalhadores começaram a reivindicar o planejamento democrático da economia. Dito de outro modo, os operários iniciam a elaboração coletiva na economia com propostas distintas em relação às do apparatchik, ou dos diretores hierárquicos. Os trabalhadores se voltaram à formulação de um projeto com independência e autonomia em relação às instâncias do poder, seja do partido, do Estado ou da fábrica.

Com vistas a enfrentar os problemas econômicos e sociais, a ala renovadora do PCT elaborou o Programa de Ação, que destacou:

O desenvolvimento insuficiente da democracia socialista no seio do partido, a
atmosfera desfavorável ao desenvolvimento da iniciativa, a proibição ou mesmo a
repressão da crítica, tudo isso impediu a correção rápida. Os órgãos do partido
pretendiam realizar as tarefas dos órgãos econômicos do Estado e das organizações
de massa. Seguiu-se uma monopolização do poder por alguns elementos. Isso
conduziu a intervenções não fundamentadas, à indiferença, ao culto da mediocridade
e a um anonimato nefasto (CPCz CC, 1998, p. 93).

Deve-se sublinhar que o Programa de Ação não pode ser entendido como um manifesto de retorno ao capitalismo, mas sim um postulado crítico do percurso social que se havia constituído na Tchecoslováquia até então. Ao mesmo tempo, os seus elaboradores seguiam o movimento da participação social, uma vez que, as mobilizações de estudantes, intelectuais e trabalhadores arrastavam politicamente a ala renovadora do PCT às medidas progressistas. Em outras palavras, o "socialismo de face humana" foi preliminarmente uma exigência dos mobilizados, mas que, posteriormente, acabou sendo encampado pelo setor liderado por Dubcek. A ala renovadora do PCT não esteve à frente dos acontecimentos, na medida em que ela seguiu os avanços das contestações populares. Os renovadores estavam dispostos a fazer concessões temporárias, sobretudo aos estudantes e à intelectualidade, com o intuito de não perder a autoridade diante do movimento de massas que florescia. 
A radicalização social prosseguiu e se materializou no importante Manifesto de Duas Mil Palavras, um documento produzido por Ludvik Vaculik, intelectual tcheco, e subscrito inicialmente por setenta destacadas personalidades da Tchecoslováquia, que reivindicava a construção do socialismo, ao mesmo tempo em que apontava os limites da experiência vivenciada no país. O texto denunciava os limites e exigia os avanços:

Foi com um sentimento de esperança que a maioria da nação aceitou o programa do socialismo. Mas as alavancas de comando não caíram em boas mãos. /.../ A linha incorreta dos dirigentes transformou o partido, que era um partido político em um agrupamento ideológico, em uma organização do poder que atraiu os egoístas ávidos de domínio, os covardes hábeis e as pessoas de má consequência. $\mathrm{O}$ afluxo desses elementos ao partido afetou sua natureza e conduta. /.../ Muitos operários acreditavam que estavam comandando, mas a direção era exercida em seu nome por um grupo de funcionários do partido e do aparelho do Estado, especialmente treinados para isso. $\mathrm{Na}$ realidade, eles ocupavam o lugar da classe deposta e se tornaram a nova autoridade. /.../ Os cabeçalhos dos jornais mostram que se trava, na imprensa, um muito cerrado combate em torno da democracia e da direção. Como produtores, os operários podem intervir através da escolha de pessoas que elegerão para a direção da empresa. /.../ Nessa primavera, como no imediato pós-guerra, uma grande oportunidade nos é dada: de novo, temos a possibilidade de tomar nas mãos nossa causa comum que, para todos os fins úteis, chamamos de socialismo(MANIFESTO DE DUAS MIL PALAVRAS, 1968, p. 218-223).

Percebe-se que a iniciativa do movimento de massas, começado por estudantes e intelectuais, desaguou em um programa com base na organização independente, alimentado pela ação autônoma dos trabalhadores em relação ao Partido e ao Estado. Diante das mobilizações populares e do Manifesto de Duas Mil Palavras respaldados por setores críticos à burocracia, torna-se possível afirmar que a Primavera de Praga caminhava para a construção efetiva do socialismo, visto que voltava-se a superar a expropriação política que a burocracia impunha aos trabalhadores e a juventude.

A posição da URSS até março de 1968 foi de que os acontecimentos de Praga seria uma querela entre tchecos e eslovacos; haja vista que, os soviéticos não externaram maiores preocupações. Após a renúncia forçada de Novotny e o fim da censura à imprensa, os burocratas soviéticos passaram a empreender ações efetivas exigindo o "controle" da situação tchecoslovaca por parte do PCT. Contudo, após a ampliação dos protestos, a conquista da liberdade de imprensa, a superação da censura e o Manifesto de Duas Mil Palavras, a burocracia moscovita e as dos países do Pacto de Varsóvia passaram a um posicionamento incisivo. Exigiu-se que se reimplantasse a censura nos meios de comunicação, que se colocassem na ilegalidade os "contrarrevolucionários" e que a "ordem" fosse restabelecida na Tchecoslováquia. Acordos foram selados nesse sentido entre o chanceler soviético Leonid 
Brejnev e o dirigente do PCT Alexander Dubcek. Entretanto, a burocracia renovadora tchecoslovaca foi incapaz de controlar o movimento que se ampliava pelo país.

\section{A invasão e as resistências}

No dia 21 de agosto, os exércitos do Pacto de Varsóvia (formado pelos países: Alemanha Oriental, Hungria, Polônia, Bulgária e URSS) invadiram a Tchecoslováquia para interromper o que seria a "contrarrevolução". Foram direcionados ao país da Europa Central cerca de sete mil tanques e 200 mil soldados. Dubcek e vários membros do governo foram levados à prisão.

Embora surpreendidos, o povo tchecoslovaco não se intimidou. Homens, mulheres e jovens foram conversar com a tropa invasora. De acordo com Vaclav Byk:

\footnotetext{
Por toda parte, as pessoas rodeavam os tanques e carros blindados, tentando explicar aos soldados que eles eram inúteis aqui. E sempre o mesmo diálogo.

- Por que foi que vieram?

- Para libertar vocês.

- Libertar de quem?

- Das forças contrarrevolucionárias.

- Mas isso não existe.

- Ah, sim! Claro que existe!

- Mas onde? Vocês viram?

-Não. - Depois, sorrindo: - Elas estão bem escondidas, por isso viemos ajudá-los a encontrarem-nas. É o nosso dever, somos amigos de vocês...

Um círculo vicioso. Eles repetiam as mesmas respostas a todas as perguntas. Os populares irritavam-se, encolerizavam-se, e os soldados encaravam-nos como criança inconscientes (1968, p.13-14).
}

Vale destacar que a burocracia tchecoslovaca estava comprometida com a negociação subordinada. Não se aventou, por parte dos dirigentes no poder, armar a população tchecoslovaca, nem mesmo reforçar as tropas nas fronteiras a fim de garantir a soberania do país.

Os tchecoslovacos responderam a invasão com resistências, que foram muito além da busca do diálogo junto aos soldados invasores. Em Bratislava, a imprensa eslovaca anunciou no primeiro dia da invasão que quatro jovens manifestantes foram fuzilados na cidade, e que dezenas foram mortos em Kósice, a leste da província. Para o conjunto do país, computou-se no primeiro dia 23 mortos e mais de 200 feridos. Segundo Kurlansky (2005), até 2 de setembro, 72 tchecoslovacos tinham sido mortos pelas tropas do Pacto de Varsóvia.

A juventude organizava barricadas contra o avanço dos tanques e atacavam os invasores com coquetéis molotov; mulheres levantavam as minissaias frente aos soldados do Pacto de Varsóvia, quando eles paravam para admirá-las, os rapazes tchecoslovacos passavam ao ataque. 
De início a resistência foi coordenada pelos meios de comunicação. Contudo, após um tanque disparar contra o edifício da Radio Praga, reduzindo-o a escombros, os dirigentes tchecoslovacos recusaram dirigir a resistência aos invasores, uma vez que clamaram ao povo o não engajamento em "atos violentos". Entretanto, a resistência passou às pichações nas cidades e as ações com as emissoras clandestinas. Grafou-se pelas ruas: "Moscou a 2000 km", "Socialismo sim, invasão não", "Não queremos liberdade sem socialismo, nem socialismo sem liberdade!"; "Liberdade a Dubcek", "Lenin acorda, Brejnev ficou louco!", "Por quê?”, "Circo russo na cidade: não alimentem os animais"; "A todos os rapazes e todas as moças! Aumentai a tensão sexual dos soldados ocupantes! Beijem diante deles!"’3.

Conjuntamente aos jovens, a classe trabalhadora enfrentou a invasão. De acordo com Pierre Broué (1979, p. 150), os mineiros e os metalúrgicos realizaram greves, os ferroviários restringiam o transporte de materiais aos ocupantes e os habitantes dos bairros operários se insurgiam contra as tropas invasoras.

Após a invasão militar, os partidários dos atos do Pacto de Varsóvia e os seus apoiadores não foram capazes de montar um novo governo na Tchecoslováquia, tendo à frente os dirigentes pró-Moscou Vassil Bilak, Alais Indra e Drahomir Kolder, como se esperava. Os três elementos do bloco conservador do PCT foram inimigos declarados da democratização, mas não conseguiram constituir legitimidade no país. A resistência do povo foi a principal barreira ao domínio imediato dos aliados aos moscovitas.

No efetivo trabalho de resistência, os tchecoslovacos organizaram o XIV Congresso do PCT. Segundo Jiri Pelikan:

Um simples chamamento pelo rádio foi suficiente para que se dirigissem a Praga os delegados ao XIV Congresso, uns por trem, outros por estradas, alguns de bicicletas ou a pé. Para conservar secreto o lugar da reunião para os ocupantes, se indicou que os delegados deveriam se apresentar numa grande fábrica de Praga, a partir da qual os operários os guiariam clandestinamente para o lugar escolhido. Levando em consideração a atmosfera dos primeiros dias de ocupação, a desorganização do trânsito e das telecomunicações, assim como os severos controles estabelecidos pelas forças de ocupação e a dispersão dos delegados por todo território tchecoslovaco, o simples fato de haver podido reunir tão rapidamente em Vysicany, periferia de Praga, uns 1200 delegados, ou seja, mais de dois terços dos eleitos, testemunha a grande maturidade política e o espírito revolucionário que animava os delegados ao XIV Congresso. Nunca o partido havia sido em tal grau a expressão dos sentimentos e das aspirações populares. (1969, p. 9-10).

\footnotetext{
${ }^{3}$ O belíssimo livro de Josef Koudelka, Invasón Praga 68 (2008), uma obra a partir das fotografias da invasão sob a Tchecoslováquia e da resistência da população, traz também, nas páginas: 82-83, 204-205 e 242-243, os registros das frases pichadas pelas ruas de Praga.
} 
Reunidos clandestinamente numa fábrica e sob a proteção dos operários, os delegados iniciaram os trabalhos. Eles elegeram um novo Comitê Central com os renovadores A. Dubcek, Oldrich Cernik, Josef Smerkovsky e Frantisek Kriegel, dirigentes que se encontravam presos. Ao passo que os nomes ligados aos conservadores obtiveram poucos votos.

As forças da ocupação militar intensificam as suas ações após o chamado "congresso clandestino" do PCT. Segundo o jornalista Jean-Claude Hallé, houve os "rumores de prisão em massa - o Pravda [o principal jornal russo] de 31 de agosto declara que os 'elementos sãos da Tchecoslováquia exigem a liquidação de 40.000 vagabundos contrarrevolucionários"” (1968, p. 233).

Entretanto, as ameaças não surtiram o efeito de desmobilização popular. Incapazes de interromper o processo revolucionário desenvolvido pelos trabalhadores, jovens e intelectuais tchecoslovacos, a direção de Moscou recorreu aos representantes da ala renovada do PCT, os dirigentes que haviam sido ordenados à prisão logo após a invasão militar.

Os soviéticos batiam pela anulação do XIV Congresso e a permanência das tropas do Pacto de Varsóvia até o advento da "normalização" no país ${ }^{4}$. O processo de normalização, segundo os soviéticos, implicaria aos dirigentes tchecoslovacos restabelecer a censura à imprensa, a universidade e a arte; esvaziar as mobilizações e a participação social; cancelar as deliberações do XIV Congresso do PCT (chamado de o "Congresso Clandestino"); e manutenção do partido único sob o comando do Estado. Em resumo, fazer o país voltar à norma de antes da situação revolucionária. Assim sendo, o termo normalização foi um eufemismo para camuflara contrarrevolução, dito de outro modo, uma forma de ocultar a exigência de subordinação tchecoslovaca aos anseios do Kremlin, e, portanto, terminar com o caminho de socialismo que se estabelecia na Tchecoslováquia.

Dubcek e os elementos de seu grupo político "renovador" serviram enquanto interlocutores válidos para controlar os protagonistas da Primavera de Praga. O retorno dos dirigentes ao poder possibilitou a "normalização", visto que os elementos mais radicalizados foram tirados de seus postos. Formou-se o governo capaz de realizar as medidas de contenção popular que não haviam sido possíveis com a invasão militar.

\section{Os Partidos Comunistas e a invasão}

\footnotetext{
${ }^{4}$ Acerca da posição veiculada na imprensa oficial da URSS sobre a Tchecoslováquia em 1968, conferir VVAA. (1968).
} 
A invasão dos exércitos do Pacto de Varsóvia provocou distintas avaliações nos Partidos Comunistas pelo mundo, resultando em divisões, decepções, refluxos das forças do partido nos seus respectivos países e recomposições programáticas.

Após o lançamento do Manifesto de Duas Mil Palavras, os Partidos Comunistas dos países que compunham o Pacto de Varsóvia lançaram uma carta endereçada ao Comitê Central do Partido tchecoslovaco. No texto lê-se:

O desenrolar dos acontecimentos em seu país provoca em nós grande inquietação. A ofensiva da reação, apoiada pelo imperialismo, contra o seu Partido e as bases do regime social da República Socialista Tchecoslovaca ameaça, segundo nossa firme convicção, fazer desviar seu país da via socialista e, por conseguinte, põe em perigo os interesses de todo o sistema socialista (CARTA DOS PARTIDOS IRMÃOS AO COMITÊ CENTRAL DO PARTIDO COMUNISTA DA TCHECOSLOVÁQUIA, 1968, p.26).

Verifica-se o posicionamento no sentido de repreender as ações do PCT nos acontecimentos, entendendo-o quanto ofensiva imperialista, o que explicita certa construção no respaldo político ao cerceamento das mobilizações de massa. Mais adiante no documento, asseverou-se:

a reação teve possibilidade de atuar publicamente diante de todo o país e de publicar sua plataforma política sob a denominação de "duas mil palavras", que contém um apelo aberto à luta contra o Partido Comunista e contra o poder constitucional, um apelo às greves e às desordens (CARTA DOS PARTIDOS IRMÃOS AO COMITÊ CENTRAL DO PARTIDO COMUNISTA DA TCHECOSLOVÁQUIA, 1968, p. 28).

Assim, os Partidos dos países do Pacto de Varsóvia foram unânimes na condenação da experiência da Primavera de Praga, entendendo-a enquanto ato "contrarrevolucionário" ao possibilitar a liberdade de imprensa, permitir o processo popular, reconhecer o direito de greve e explicitar a pluralidade política.

A resposta do PCT chegou três dias depois. Na missiva, reiterava-se a defesa das conquistas históricas do socialismo e da segurança, ao mesmo tempo que explicava: “O conteúdo básico de nosso processo a partir de janeiro está justamente no acréscimo da força interna e da estabilidade do regime socialista e com isso também de nossas alianças". ( PCT, 1968, p. 38).

O resultado da troca de cartas foi a convocação de um encontro em Bratislava, no qual foi elaborado um documento comum de todos os Partidos Comunistas membros do Pacto de Varsóvia. Na chamada Declaração da Bratislava encontra-se apenas referências gerais acerca da conjuntura mundial, sem pormenorizar os aspetos específicos de cada país, ou da Tchecoslováquia. Os seis "Partidos irmãos" assinaram que: 
Os membros da conferência consideram de seu dever chamar a atenção dos povos para o fato de que, em consequência da política agressiva do imperialismo, o clima internacional se mantém complexo e perigoso. Nessas condições, os partidos irmãos dos países socialistas, inspirando-se nos interesses da luta pelo reforçamento dos princípios da coexistência pacífica dos Estados de diferentes estruturas sociais, confirmam mais uma vez sua vontade de ajustar e coordenar suas ações na arena internacional. (DECLARAÇÃO DE BRATISLAVA, 1968, p.51).

Após a assinatura da carta conjunta, Dubcek pronunciou um discurso expressando contentamento pelo êxito das conversações, ressaltou que a soberania nacional tchecoslovaca estava assegurada, ademais, enfatizava que as boas relações com a União Soviética eram essenciais.

Entretanto, a crise política se agravou nos dias sequentes. As visitas do líder iugoslavo Josep Tito, em 9 de agosto, e a do romeno Nicolae Ceausescu, no dia 15, ambos desafetos de Moscou por seguir a linha de construção do socialismo independente da URSS irritaram os dirigentes soviéticos. Além disso, continuava a radicalização do povo em busca do socialismo democrático, o que revelava a "incapacidade de controle da situação" pelos dirigentes renovadores do PCT. No dia 21 de agosto ocorreu a invasão liderada pelos soviéticos sobre a Tchecoslováquia.

Diante da invasão, os Partidos Comunistas dos países do Pacto de Varsóvia apoiaram as suas tropas, sob a alegação de que era necessário conter o avanço da contrarrevolução nas terras do país de Europa Central, com vistas a garantir a segurança do mundo socialista. Como justificativa, expunham as linhas da carta de Bratislava e dos tratados do bloco socialista, que, segundo eles, previam tal procedimento militar na situação vislumbrada. Assim, reivindicando a carta assinada em Bratislava, os países do Pacto de Varsóvia pretenderam uma roupagem jurídico-política para legitimar a invasão e o desrespeito à soberania nacional tchecoslovaca.

O líder cubano Fidel Castro, por seu turno, em nome de seu partido e governo, declarou:

$\mathrm{Eu}$ penso que a justificativa (da intervenção) se encontre no fato de que a Tchecoslováquia está marchando para o capitalismo. Esta justificação é suficiente. Não há nenhuma necessidade de servir-se de folha de figo para desculpar-se. É inútil pretender que a soberania tchecoslovaca não tenha sido violada, ela foi violada, e de maneira flagrante, e ninguém pode contestar este fato de um ponto de vista legal (RCB, 1968, p. 76).

Nota-se que Fidel Castro justificou a invasão de forma explícita sem buscar o subterfúgios do acordo de Bratislava. O perigo da contrarrevolução justificaria a medida de violar a soberania nacional Tchecoslováquia. Torna-se importante lembrar que o ano de 1968 em Cuba representou o momento de fechamento do processo revolucionário, de aproximação 
firme à aliança com Moscou, resultando em centralização de medidas econômicas e da formas de poder nas instância do Partido Comunista Cubano e do Estado.

Também favorável a invasão esteve o Partido Comunista Brasileiro, que declarou:

As forças militares dos cinco países foram enviadas à Tchecoslováquia não para interferirem em seus assuntos internos, mas para garantirem a independência da Tchecoslováquia diante da ingerência imperialista, para possibilitarem às forças socialistas desse país prosseguirem na edificação da sociedade socialista e no processo de ampliação da democracia socialista (PCB, 1968, p. 98).

Assim, o PCB registrou que por meio da invasão militar soviética se garantiria o processo da ampliação da democracia socialista no país (sic). O que expõe, no caso da invasão soviética sob a Tchecoslováquia, o alinhamento cego dos pecebistas à política do Kremlin.

Em outro diapasão político, o Partido Comunista Chinês denunciou a invasão da Tchecoslováquia enquanto um ato do "imperialismo soviético", repetindo a conceituação que usava para caracterizar a formação social da URSS naquele momento, posicionando-se contra a invasão.

N. Ceausescu, dirigente do Partido Comunista Romeno, denunciou a

\begin{abstract}
flagrante violação da soberania nacional de um país socialista irmão. /.../ É inconcebível que um Estado socialista, que Estados socialistas violem a liberdade e a independência de um outro Estado. /.../ O Problema da escolha dos caminhos para a edificação socialista é um problema interno de cada partido, de cada Estado, de cada povo. (RCB, 1968, p. 74).
\end{abstract}

Pode-se perceber que Ceausescu relacionou o ato da invasão soviética e a violação da soberania nacional tchecoslovaca ao tema caro aos comunistas romenos, o problema da dominância soviética, visto que desde o início da década de 1960, eles buscavam o caminho político com independência em relação à URSS.

A Liga Comunista da Iugoslávia produziu um documento condenando a invasão soviética. A declaração do partido de Tito denunciou a falsidade dos argumentos sobre a suposta “contrarrevolução na Tchecoslováquia”, uma vez que o conjunto de reformas estava respaldado pelo PCT e na imensa maioria do povo. Ademais, fez referência aos desafios sociais no processo de transição ao socialismo:

Não foi por acaso que o Partido Comunista da Tchecoslováquia deu início ao equacionamento das contradições e problemas acumulados no desenvolvimento social do seu país. Isso é o reflexo das necessidades da sociedade desenvolvida e da impossibilidade de serem os interesses do povo e do socialismo concretizados no quadros das relações burocráticas estatais. Nisso a direção do Partido Comunista encontrou pleno apoio dos membros, da classe operária e do povo da República Socialista da Tchecoslováquia. As correntes anti-socialistas na Tchecoslováquia não puderam criar raízes no povo e continuam sendo apenas um subproduto do processo 
precisamente porque as forças socialistas conscientes, com os comunistas à frente, desempenham com êxito o seu papel histórico. Por isso o golpe contra o Partido Comunista, contra a sua direção e contra a classe operária tchecoslovaca, que são os únicos depositários e fiadores do progresso e do socialismo, não significa ajuda ao socialismo, mas sim estrangulamento do seu desenvolvimento (LCI, 1968, p. 104105).

Desse modo, além de denunciar o desrespeito à soberania nacional tchecoslovaca, bem como o golpe contra o PCT e o povo impetrado pelos países do Pacto de Varsóvia, a posição da LCI frisou os limites do planejamento central burocratizado para enfrentar o desenvolvimento econômico, realçando a tentativa dos comunistas tchecoslovacos em buscar um caminho diferente, inspirado no percurso da própria Iugoslávia, por meio da descentralização do planejamento. Sendo assim, o documento oficial iugoslavo respaldava explicitamente o projeto da ala reformadora cerceado pela invasão militar.

$\mathrm{Na}$ Europa Ocidental a repercussão foi tremenda para os Partidos Comunistas. As organizações comunistas com maior enraizamento no movimento dos trabalhadores e com forte expressão eleitoral à época se posicionaram contra a invasão. O Partido Comunista Francês publicou:

o Comitê Central, fazendo sua a declaração do Departamento Político, de 21 de agosto, desaprova a intervenção militar na Tchecoslováquia. É ao Partido Comunista da Tchecoslováquia que caberá, respeitadas suas obrigações internacionais, encontrar em si mesmo, na classe operária e no povo tchecoslovaco, no apoio dos países socialistas e do conjunto dos partidos irmãos, as forças necessárias para salvaguardar e desenvolver o socialismo em sua pátria. (PCF, 1968, p. 92).

O Partido Comunista Italiano, a maior agremiação comunista do Ocidente, na voz de seu Secretário Geral à época, o deputado Luigi Longo, expressou:

Manifestamos de maneira clara o nosso profundo dissenso e a nossa reprovação pela intervenção militar da URSS e de outros países do Pacto de Varsóvia na Tchecoslováquia. O nosso dissenso e a nossa reprovação foram expressos pelo escritório político e pela direção do Partido quando e teve notícia da intervenção (RCB, 1968, p. 80).

A invasão soviética sobre a Tchecoslováquia teve profundo impacto na opinião pública e no movimento dos trabalhadores. Os Partidos Comunistas ocidentais tiveram de explicar às suas bases a atitude intervencionista, o que levou à desgastes políticos e a ampliação de dúvidas acerca da capacidade de direção dos moscovitas no processo de revolução mundial. As ocorrências da Primavera de Praga foram componentes que levaram os PCs europeus à reformulação de suas plataformas políticas, que anos mais tarde ficou conhecido como eurocomunismo. Tratou-se de uma recomposição programática acerca dos caminhos a serem trilhados pelos países capitalistas avançados ao socialismo, respaldado no princípio da 
“democracia como valor universal”. Para a visão eurocomunista, o socialismo seria a radicalização da democracia nos limites das instituições do Estado. Em consequência, ocorreu o afastamento dos PCs da Europa Ocidental em relação aos ditames de Moscou.

Torna-se importante considerar que os dirigentes dos Partidos Comunistas dos países da Europa Ocidental não fizeram um balanço de conjunto do que representou historicamente as direções burocratizadas nos países do Leste Europeu. Tampouco se pautaram pela defesa dos conselhos operários e da democracia dos trabalhadores. Eles criticaram o poder autocrático nos países comunistas e restringiram a alternativa dos trabalhadores à forma do Estado Democrático de Direito, respeitando a propriedade privada e conciliando aos interesses do imperialismo a serem administrados.

A atitude da URSS frente a Primavera de Praga levou ao aprofundamento da crise do movimento comunista, de modo que evidenciou o fim da hegemonia de Moscou, que já estava impactada desde o pós-II Guerra, com a revolução chinesa e iugoslava, questionamento que teve sequência nos anos 50 e 60 . Contudo, após 1968 chegou a seu patamar irreversível, levando a novas experiências programáticas. Os Partidos Comunistas da Europa Ocidental que possuíam certa expressão política doravante não aceitariam tranquilamente as ordens do Kremlin, sobretudo os Partidos italiano, francês e, posteriormente, o espanhol. A União Soviética manteve o seu bloco de países unido por mais vinte anos somente devido à ameaça de intervenção militar.

\section{Os Conselhos Operários}

Os movimentos dos trabalhadores somaram-se à Primavera de Praga no mês de março, como já mencionado. Vale destacar que de início, os operários não se sentiam representados pela camada dirigente do Estado e do Partido mandatária desde 1948, que promovia o planejamento centralizado e burocratizado; tampouco se reconheciam representados na ala renovadora do PCT, que advogava o programa da diferenciação salarial enquanto uma das formas de superação da crise econômica. Sendo assim, após os acontecimentos que levaram à renúncia de Novotny, os trabalhadores se meteram a discutir a autogestão nas fábricas buscando a construção de uma alternativa, a partir dos conselhos formados no calor do ascenso das lutas. Em abril de 1968, com a aprovação do Programa de Ação, a ala renovada foi forçada a registrar no documento a "autogestão da propriedade social"; no entanto, sem definir os contornos exatos do que significaria na prática. Na sequência, observa-se os esforços dos operários para a disputa programática com a ala reformadora da burocracia, segundo Robi Morder, 
A partir de meados de maio, os comitês e as assembleias se reúnem para preparar uma lei acerca da 'empresa socialista'. Surgem greves contra a incompetência de alguns diretores de empresas. No início de junho começam a estabelecer-se os conselhos nas fortalezas operárias de CKD (fábrica W. Pieck) e na Skoda Plzen (2008).

Nesse passo, avança-se nas contradições entre os trabalhadores e os dirigentes fabris. Como narra Morder:

\begin{abstract}
Partindo de problemas materiais e econômicos, o movimento dos conselhos toma uma dimensão política: a participação democrática tanto na empresa como na sociedade. Por um lado, os economistas e os diretores, apoiados pelos órgãos dirigentes do partido e do governo, não pensão atribuir aos conselhos mais que poderes limitados no sistema de cogestão, para criar um clima favorável a racionalização da gestão e o aumento da produtividade. O Partido utilizava o termo "conselho de empresa" no lugar de "conselho operário" (2008).
\end{abstract}

Torna-se importante registrar que a ampliação substantiva dos conselhos de fábrica ocorreu após a ocupação das tropas do Pacto de Varsóvia, enquanto forma de rebeldia operária seguiram na construção de uma alternativa desde à base da sociedade. O movimento dos conselhos operários empolgou o filósofo marxista húngaro G. Lukács, que enxergava esse processo como a única alternativa progressista às estruturas do "socialismo", pois a democracia socialista somente poderia ser efetivada se constituir enquanto "uma democracia da vida cotidiana, tal qual apareceu nos conselhos operários de 1871, 1905 e 1917 e tal qual existiu nos países socialistas e deve aí ser novamente despertada" (apud NETTO, 2008).

Segundo Morder, como forma de resistência:

Os conselhos se multiplicam: 19 em setembro, 120 ao final de 1968, apesar da declaração governamental de 24 de outubro que pontua não considera útil continuar o experimento. Em janeiro de 1969, a fábricaSkoda em Pilsen, as delegações de 182 grandes empresas que representam a 890.000 empregados, ou seja, mais uma quarta parte dos trabalhadores da Tchecoslováquia, se reúnem em um encontro consultivo (MORDER, 2008).

Pode-se perceber que a construção da alternativa pelos trabalhadores seguia para além da autogestão isolada por empresa. Os esforços de organização denotam que se vislumbrava enquanto perspectiva o planejamento democrático, mas centralizado. Ademais,

O movimento continua. O congresso de Sindicatos se reúne de 4 a 7 de março de 1969 e pede a legalização dos conselhos operários, pressionando ao governo para que aprove a lei referente a empresa socialista, e para que condene a intervenção do Pacto de Varsóvia (MORDER, 2008).

Em junho de 1969, mais de 300 conselhos estavam em funcionamento, pouco tempo depois, o número chegou a 500, com mais de 1 milhão de trabalhadores envolvidos. Nota-se 
que a despeito da invasão liderada pelos soviéticos, os trabalhadores realizaram ações no sentido de sua organização, bem como na construção de formas de poder alternativas.

No esforço de um compromisso com os soviéticos, a direção dubcekiana brecou o processo de constituição dos conselhos operários nos locais de trabalho, bem como da formulação da alternativa dos trabalhadores pautada na autogestão democrática e centralizada. Em fevereiro de 1969, o Comitê Central do PCT aprovou a proposta "realista" de limitar a cogestão, uma vez que reconheceu somente um terço da representação operária eleita e, além disso, com o direito de veto por parte do representante do Estado e dos diretores fabris.

Pode-se observar que a Primavera de Paga foi sendo estrangulada. Em abril de 1969 a censura é restabelecida, cerceando o trabalho dos profissionais da imprensa, ao passo que impactou os ganhos com a liberdade de informação pela sociedade. No dia 17, Dubcek se vê obrigado a abandonar a liderança do PCT, sendo substituído por Gustav Husak, dirigente do Partido radicalmente contrário às deliberações do "Congresso Clandestino" e dos movimentos por autonomia. Tratava-se de um sujeito palatável aos apparatchik da Tchecoslováquia e à burocracia de Moscou. Por conseguinte, abandona-se a discussão da autogestão industrial e os conselhos operários são fechados.

Com Husak, segue-se a onda repressiva de forma explícita, o sindicato estudantil é dissolvido em junho, e os sindicatos de trabalhadores sofrem verdadeiros expurgos. Na fábrica Skoba, segundo Morder,

o conselho decide se dissolver em novembro de 1969. Durante o ano de 1970, 50.000 sindicalistas foram tirados de suas funções. Em setembro de 1970, o sindicato de Escritores se dissolveu. No Partido Comunista, os expurgos chegaram a meio milhão de membros (MORDER, 2008).

Portanto, operou-se o estrangulamento da revolução operária e juvenil tchecoslovaca. A construção do socialismo não foi interrompida apenas pelos tanques do Pacto de Varsóvia, mas também pela ação da burocracia renovadora que aceitou a função de instrumento de "normalização".

Uma vez avançada a contrarrevolução sob a direção de figuras públicas da "ala renovada", somados aos comunistas conservadores e a vigilância das tropas do Pacto de Varsóvia, ocorreu a recomposição dos grupos no interior do PCT, formando o bloco político "realista", os novos dominantes nas instâncias partidária e estatal. Nos meses subsequentes, efetuou-se as prisões dos ativistas da Primavera de Praga, o controle sobre os profissionais da imprensa, trabalhadores das fábricas, professores e estudantes. Os membros pacificadores do processo foram sendo descartados da vida política, na medida em que se processava o refluxo 
do movimento devido à desmobilização e a repressão. Asfixiou-se a experiência de construção do "socialismo com face humana".

\section{A revolução asfixiada}

A Primavera de Praga representou a emergência do processo revolucionário, mas que não foi completado. Os elementos que formaram a estação transformadora na Tchecoslováquia contaram com as movimentações da juventude para que tivessem as suas demandas ouvidas e contempladas no "socialismo"; a onda contestatória da intelectualidade: artistas, professores, jornalistas e acadêmicos engajados na construção autêntica do socialismo, isto é, intelectuais combatendo pela igualdade substantiva com a liberdade de expressão e liberdades políticas; estudantes que organizaram as manifestações de ruas; e, posteriormente, os trabalhadores que trouxeram a consigna de organização autônoma e independente em relação ao Estado, viabilizaram os conselhos operários para o controle social da produção, em contraponto ao domínio dos apparatchik e ao dos diretores das empresas burocraticamente administradas.

Os representantes da ala renovadora do Partido Comunista da Tchecoslováquia seguiram as mobilizações e, durante algum tempo, conseguiram incorporá-las às instâncias da organização. Assim sendo, os dirigentes renovadores do PCT não foram os principais protagonistas na onda contestatória.

No processo da Primavera de Praga emergiu o projeto de constituição de um sistema socialista com pluralismo e ampla autogestão apoiada nos conselhos operários, a partir das mobilizações sociais, mas tal processo foi interrompido pela ocupação militar liderada por Moscou e pelas ações políticas dos "realistas" do PCT.

A invasão desencadeada pelos países do Pacto de Varsóvia sob a Tchecoslováquia, dirigida pela URSS, ocorreu pelo pânico de contágio por parte das burocracias do "socialismo" do Leste Europeu, uma vez que as mobilizações poderiam desencadear a revolução política no mundo "socialista", o que levaria ao fim à dominação da casta dirigente expropriadora política do proletariado. A construção autêntica do socialismo na Tchecoslováquia, a igualdade calcada na liberdade e na participação, impactaria o poder e os privilégios das camadas dirigentes dos países do bloco liderado pelos soviéticos.

A contrarrevolução sob a forma de "normalização" da Tchecoslováquia foi realizada com a invasão militar e a colaboração da ala renovada do PCT, que se prestou à função de pôr fim à resistência popular e reestruturou o poder burocrático. 
Os eventos de 1968 pelo mundo representaram a emergência de um novo contexto, na medida em que se pôde evidenciar o esgotamento do equilíbrio de forças políticas estabelecido desde o pós-II Guerra Mundial. Essa alteração deveu-se à luta do povo vietnamita, que impôs reveses às tropas estadunidenses na Ásia; a situação revolucionária na França, deflagrada pela juventude e pelos trabalhadores durante maio-junho daquele ano; e as mobilizações na Tchecoslováquia, com base nos estudantes, intelectuais e operários pelo socialismo com democracia.

No ano de 1968 a coexistência pacífica entre as potências capitalistas e a URSS ganhou um elemento novo, na medida em que frente à situação revolucionária operária-juvenil no plano mundial ocorreu certa colaboração contrarrevolucionária entre o imperialismo e a burocracia soviética para a manutenção do status quo. Durante a crise de maio-junho de 1968 na França, aos soviéticos não interessava a desestabilização da ordem capitalista francesa, uma vez que, na área de influência geopolítica da URSS, enfrentava-se o processo de construção do socialismo na Tchecoslováquia com base na participação social de forma autônoma e independente, superando a burocracia. Para o controle da situação na Tchecoslováquia, Moscou solicitava a cumplicidade, ou ao menos a neutralidade dos países imperialistas ocidentais.

\section{Referências}

BENJAMIN, W. "Sobre o conceito da história". In. Magia e técnica, arte e política. Obras Escolhidas vol. 1. São Paulo: Editora Brasiliense, 1994, p: 222-232.

BROUÉ, P. A primavera dos povos começa em Praga. Trad. Maria Luiza Gonçalves, J. Teixeira Coelho Neto. São Paulo: Kairós, 1979.

BYK, V. "O primeiro morto". In. DESGRAUPES, P.; DUMAYET, P. (Coords.). Praga: quando os tanques avançam. Trad. Álvaro Cabral. Rio de Janeiro: Editora Expressão e Cultura, 1968, pp: 11-25.

CARTA DOS PARTIDOS IRMÃOS AO COMITÊ CENTRAL DO PARTIDO COMUNISTA DA TCHECOSLOVÁQUIA. In. Tchecoslováquia. Análise dos aspectos políticos, econômicos e culturais da crise de Agosto. Revista Civilização Brasileira. Caderno Especial 3. Rio de Janeiro, 1968, pp:1968, pp. 25-33.

CLAUDÍN, F. A oposição no "socialismo real": União Soviética, Hungria, Polônia, Tchecoslováquia: 1953/1980. Trad. Felipe José Lindoso. Rio de Janeiro: Editora Marco Zero, 1983.

CPCz CC. ActionProgram, April 1968 (Excerpts). In. NAVRATIL, J. The Prague Spring 1968. Budapest: Central European University Press, 1998, pp: 93-95. 
DECLARAÇÃO DE BRASTILAVA. In: Tchecoslováquia. Análise dos aspectos políticos, econômicos e culturais da crise de Agosto. Revista Civilização Brasileira. Caderno Especial 3. Rio de Janeiro, 1968, pp:1968, pp. 47-53.

DUBCEK, A., with Jiri Hochman. Hope dies last: theautobiographyof Alexander Dubcek. London: Harper Collins, 1993.

HALLÉ, J-C. "Somos todos Dubceks". DESGRAUPES, P.; DUMAYET, P. (Coords.). Praga: quando os tanques avançam. Trad. Álvaro Cabral. Rio de Janeiro: Editora Expressão e Cultura, 1968, pp:193-236.

KOUDELKA, J. Invasión Praga 68. Barcelona: Lunwerg Editores, 2008.

KURLANSKY, M. 1968: o ano que abalou o mundo. Trad. Sônia Coutinho. Rio de Janeiro: Ed. José Olympio, 2005.

KUSIN, V. The intellectual origins of the Prague Spring : the development of reformist ideas in Czechoslovakia 1956-1967. Cambridge: Univ. Press, 1971.

LCI. Resolução do Comitê Central da Liga dos Comunistas da Iugoslávia. In: Tchecoslováquia. Análise dos aspectos políticos, econômicos e culturais da crise de Agosto. Revista Civilização Brasileira. Caderno Especial 3. Rio de Janeiro, 1968, pp: 100-109.

LÖBL, E.; POKORNY, D. Afinal, a verdade. Rio de Janeiro: Laudes, 1968.

MANIFESTO DAS DUAS MIL PALAVRAS. In: Tchecoslováquia. Análise dos aspectos políticos, econômicos e culturais da crise de Agosto. Revista Civilização Brasileira. Caderno Especial 3. Rio de Janeiro, 1968, pp: 217-224.

MORDER, Robi. La Primavera de Praga y los consejos obreros (1968/1969). Data da publicação no site: 18/01/2018. http://www.rebelion.org/noticia.php?id=236749. Acesso em 16 de julho, de 2018.

NETO, J. P. "Introdução: sobre Lukács e a política. In. LUKÁCS, G. Socialismo e democratização. Rio de Janeiro: Ed. UFRJ, 2008, pp: 07-36.

PCB. Resolução sobre o Problema tchecoslovaco: Defesa do Socialismo e da unidade do movimento comunista. In: Tchecoslováquia. Análise dos aspectos políticos, econômicos e culturais da crise de Agosto. Revista Civilização Brasileira. Caderno Especial 3. Rio de Janeiro, 1968, pp: 93-99.

PCF. Resolução do Departamento político do Partido Comunista Francês. In: Tchecoslováquia. Análise dos aspectos políticos, econômicos e culturais da crise de Agosto. Revista Civilização Brasileira. Caderno Especial 3. Rio de Janeiro, 1968, pp:90-92.

PCT. Resposta do CC do Partido Comunista da Tchecoslováquia. In: Tchecoslováquia. Análise dos aspectos políticos, econômicos e culturais da crise de Agosto. Revista Civilização Brasileira. Caderno Especial 3. Rio de Janeiro, 1968, pp:1968, pp. 35-46. 
PELIKAN, J. Le congrés clandestin: protocole secret et documents Du XIVe congrès extraordinaire du Parti Communiste Tchécoslovaque. Seuil: Paris, 1969.

RABEY, P.; DUARTE, O. D.; BRUNO, D. La Primavera de Praga, revisitada. La revolución política y eliniciodelfin de la "terceravía". 2008. In: http://studylib.es/doc/4490304/laprimavera-de-praga--revisitada.-larevoluci\%C3\%B3n-pol\%C3\%ADtica. Acesso em 12 de julho de 2018.

RCB. [REVISTA CIVILIZAÇÃO BRASILEIRA]. "Tomada de posição dos Partidos Comunistas". In: Tchecoslováquia. Análise dos aspectos políticos, econômicos e culturais da crise de Agosto. Revista Civilização Brasileira. Caderno Especial 3. Rio de Janeiro, 1968, pp: 73-87.

TIGRID, P. A primavera de Praga. Trad. Sérgio de Queirós Duarte. Rio de Janeiro: Biblioteca do Exército/Laudes, 1968.

VVAA. Los acontecimientos em Checoslovaquia. Moscu: Grupo de Prensa URSS, 1968. WALTER, G. "O que queriam os tchecos". In. DESGRAUPES, P.; DUMAYET, P. (Coords.). Praga: quando os tanques avançam. Trad. Álvaro Cabral. Rio de Janeiro: Editora Expressão e Cultura, 1968, pp: 87-118.

WOODS, A. "Tchecoslováquia 1968: a Primavera dos povos”. In: Revista América Socialista, n'12. São Paulo: Editora Marxista, 2018, p: 4-16.

Recebido em setembro de 2018

Aprovado em novembro de 2018 